\title{
A Study on "Kashgar City Circle" Industry Development in the Contest of the Silk Road Economic Belt
}

\author{
Pan Jie ${ }^{1, \mathrm{a}}$, Bai Xiao*2,b(Corresponding Author) \\ ${ }^{1}$ Faculty of Transportation and Management, Xinjiang Vocational and Technical College of Communications, Urumqi, Xinjiang, China \\ ${ }^{2}$ Postdoctoral Innovation Practice Base, Xinjiang Vocational and Technical College of Communications, Urumqi, Xinjiang, China
}

\begin{abstract}
Kashgar City Circle is an important node of the new The Silk Road economic belt.Kashgar City Circle will serve as a new economic growth pole in the western region and will promote the rapid development of regional economy.The development of industry is an important driving force for regional economic development.This paper analyzes the four indicators of total output value,output value growth rate,employed population and labor productivity of the 18 industrial sectors of Kashgar City Circle from 2012 to 2016.Combined with the opportunities brought by the Silk Road economic belt background to the development of the Kashgar City Circle industry,this paper puts forward the current policy recommendations for the development of the Kashgar City Circle industry.
\end{abstract}

\section{Introduction}

Kashgar is the traffic hub of the ancient The Silk Road, the traffic hub of the new The Silk Road economic belt, and a major channel for trade with neighboring countries. The Kashgar area is adjacent to the Kizilsu Kirgiz Autonomous Prefecture (hereinafter referred to as Kzhou), the northwest and southwestern regions of Kyrgyzstan are adjacent to 6 countries in Central Asia and South Asia, bordering Kyrgyzstan and Tajikistan, and 254 pass through the mountain pass and the second Port of each country."Kashgar City Circle" is defined as the urban clusters in the Kashgar area and the Kezhou area, with an area of 182,600 square kilometers. Kashgar City Circle, as the new growth pole in the west, its industrial development directly affects the development of the regional economy. The planning of Kashgar Urban Agglomerations was only proposed in the 13th Five-Year Plan recently. Therefore, there are relatively few researches on Kashgar Urban Agglomeration. The research on Kashgar region industry mainly includes: research on Kashgar urban agglomeration industry from the perspective of industrial structure order[1];from the perspective of industrial isomorphism among cities and towns, the paper studies the industries of cities and towns in Kashgar Urban Agglomeration[2];to study the integration of Kashi and Atushi from the perspective of urbanization combination[3];from the aspects of labor productivity and output value, choose the comparative advantage industries in Kashgar Urban Agglomeration[4]; combining resources and regional development planning, the paper puts forward countermeasures for the industrial transformation and development of Kashgar urban agglomeration[5].Other scholars have conducted in-depth research on the adjustment and optimization of industrial structure [6-10],the current economic development situation[11-12],the impact of fixed asset investment on industrial structure change[13-14].However, based on the background of The Silk Road economic belt, there are relatively few suggestions for Kashgar City Circle industrial development policy. This article starts with the current status of Kashgar City Circle industry development and analyzes the current industrial development of Kashgar City Circle. In addition, combined with the background of The Silk Road economic belt,it proposes policy recommendations for the development of Kashgar City Circle industry.

\section{Geographic Location of "Kashgar City Circle"}

The Silk Road economic belt starts from Chang'an,passes through Dunhuang,Jiayuguan,and enters Xinjiang,and then leads to Central Asia through Jingyin,Aksu,Kashgar,and Tashkurgan counties.Among them,the Kashgar area includes four counties and cities,namely Kashgar City,Shache County,Yecheng County and Tashkurgan County,which is not only a necessary road for the ancient The Silk Road economic belt,but also an important node of the new The Silk Road economic belt.It can be seen that the social and economic development of the Kashgar region has an important impact on the promotion of The Silk Road economic belt initiative.

Kashgar City Circle is located in the northwestern border of China.It is an important channel for the "Ancient Silk Road economic belt". Due to its long history,Kashgar City Circle is relatively remote.Therefore,the region's economy is relatively backward.It has always been based 
on agriculture.Although the mineral resources are relatively rich,due to geographical location and transportation problems,no powerful pillar industries have been formed,and the service industry has been relatively stable. The proposal of "New Silk Road economic belt" makes Kashgar City Circle not only a window for West Asia,but also as the "Five Centers" in the western region.On May 22,2015, the Xinjiang Autonomous Region Development and Reform Commission recently stated that the overall idea for the construction of the core area of Xinjiang The Silk Road economic belt is to take the "three channels" (the three channels of north,middle and south) as the main line.In addition,it should be supported by "three bases" (national large-scale oil and gas production and processing bases, large-scale coal,coal,electricity,coal chemical bases,and large-scale wind power bases), and "five major centers" (transport hub centers, trade and logistics centers, financial centers,cultural sciences and education),medical service center),with "Ten Import and Export Industrial Clusters" as the carrier,make full use of two resources and two markets,promote reform and innovation, and accelerate the pace of opening up.Among them,the location of Kashgar City Circle is the central point of the "five centers",and Kashgar City Circle will become a new economic growth pole in Northwest and Central Asia.

\section{Current Development of Industry at Kashgar City Circle}

"Kashgar City Circle" mainly includes: 1 county-level city, 10 counties, and 1 autonomous county under the jurisdiction of Kashgar region: Kashgar City, Shufu County, Shule County, Yingjisha County, Yuepuhu County, Jiashi County, Shache County, Zepu County, Yecheng County, Maigaiti County,Bachu County and Tashkurgan Tajik Autonomous County. Kezhou has jurisdiction over 1 county-level city and 3 counties, namely Atushi City, Akto County, Wuqia County and Aheqi County.That is,the current Kashgar area and the Kezhou area are composed of 2 cities, 13 counties and 1 autonomous county.

Table1. Total Output of Each Industrial Sector of Kashgar City Circle in 2012-2016 Unit: Ten thousand Yuan

\begin{tabular}{|c|c|c|c|c|c|}
\hline $\begin{array}{l}\text { Industrial Sector } \\
\end{array}$ & 2012 & 2013 & 2014 & 2015 & 2016 \\
\hline Agriculture,forestry,animal husbandry and fisheries & 1848556 & 1906522 & 1959501 & 1991341 & 2137401 \\
\hline Extractive industry & 195831 & 206837 & 175766 & 132673 & 107778 \\
\hline Food processing & 157312 & 175018 & 181385 & 162334 & 184465 \\
\hline Textile and clothing industry & 64533 & 24419 & 43149 & 55889 & 95594 \\
\hline Wood processing,furniture,paper,printing industry & 2330 & 2650 & 6656 & 25287 & 21635 \\
\hline $\begin{array}{l}\text { Medicine,rubber,chemical raw materials and chemical products } \\
\text { manufacturing }\end{array}$ & 47165 & 34017 & 38197 & 37363 & 54263 \\
\hline Non-metallic mineral products industry & 221583 & 230661 & 194419 & 179903 & 172864 \\
\hline Metal products,smelting and rolling processing industry & 260404 & 287447 & 231418 & 162707 & 166242 \\
\hline Equipment manufacturing & 0 & 0 & 12178 & 38575 & 16633 \\
\hline Electricity,water and gas production & 317399 & 327812 & 357449 & 204797 & 113369 \\
\hline Construction industry & 692129 & 755845 & 57821 & 57210 & 750475 \\
\hline Transportation,warehousing and postal services & 182504 & 176290 & 276679 & 175054 & 146181 \\
\hline Wholesale and retail trade & 599461 & 616366 & 622090 & 176012 & 478053 \\
\hline Accommodation and catering & 116050 & 130620 & 132471 & 136757 & 91402 \\
\hline Financial industry & 130756 & 135770 & 136440 & 138066 & 139075 \\
\hline Real estate & 114549 & 130328 & 132071 & 130676 & 120206 \\
\hline Profitable service industry & 221617 & 211851 & 212207 & 213665 & 202440 \\
\hline Non-profit service industry & 954052 & 995248 & 1007174 & 1014808 & 882445 \\
\hline Total output & 6126231 & 6347700 & 6477070 & 5733118 & 5880521 \\
\hline
\end{tabular}

Note: The data in the table is calculated with 2012 as the base period

In order to facilitate statistical analysis,this paper divides the industry into 18 sectors. The data in this section comes from the Kashgar regional statistical yearbook 2013 2017 and the Kizilsu Kirgiz regional statistical yearbook 2013 2017.

As can be seen from table 1,the total output value of Kashgar City Circle showed a downward trend in 20122016. The total output value of Kashgar City Circle in 2012 was 61.261231 million yuan,and the total output value in 2013 only increased by $3.6 \% ; 2014$ compared with 2013 The annual total output value increased by $2 \%$; the total output value declined in 2015 , and the total output value decreased by $6.4 \%$ compared with 2012 ; the total output value in 2016 increased slightly from 2015,but still decreased by 4\% compared with 2012 .

From 2012 to 2016, the industry sectors with obvious growth mainly include agriculture, forestry, animal husbandry and fishery, food manufacturing, textile and clothing industry, wood processing, furniture, papermaking, printing industry, medicine, rubber, chemical raw materials and chemical products manufacturing, equipment manufacturing, construction, wholesale and retail; The industrial sectors that experienced a decline in output value from 2012 to 2016 include extractive industries, non-metallic mineral products industry, metal products, smelting and rolling processing industries, power, water and gas production industries, transportation, warehousing and postal industries, accommodation and restaurants, profitable service industry, non-profit service industry; from 2012 to 2016 , the output value was maintained at a relatively stable level, and there were neither major growth nor major reductions in the financial sector and real estate sector. According to Table 1, the growth rate of output value of various industrial sectors of Kashgar City Circle from 2013 to 2016 can be calculated (see Table 2 for details).

From 2012 to 2016,Kashgar City Circle's employment 
in various industrial sectors did not change much. The total employed population of Kashgar City Circle was 251,779 in 2012, and it increased to 290,958 in 2016, with a growth

Table2. Growth Rate of Each Industrial Sector of Kashgar City Circle in 2013-2016 Unit: 100\%

\begin{tabular}{|c|c|c|c|c|c|}
\hline Industrial Sector & 2013 & 2014 & 2015 & 2016 & $\begin{array}{c}\text { Average } \\
\text { growth } \\
\text { rate }\end{array}$ \\
\hline Agriculture,forestry,animal husbandry and fisheries & 0.0313 & 0.0277 & 0.0162 & 0.0733 & 0.0371 \\
\hline Extractive industry & 0.0562 & -0.1502 & -0.2451 & -0.1876 & -0.1317 \\
\hline Food processing & 0.1125 & 0.0363 & -0.105 & 0.13632 & 0.0450 \\
\hline Textile and clothing industry & -0.6216 & 0.7670 & 0.2952 & 0.71043 & 0.2877 \\
\hline Wood processing,furniture,paper,printing industry & 0.1371 & 1.5121 & 2.7991 & -0.1444 & 1.0760 \\
\hline $\begin{array}{l}\text { Medicine,rubber,chemical raw materials and chemical products } \\
\text { manufacturing }\end{array}$ & -0.2787 & 0.1228 & -0.0218 & 0.4522 & 0.0686 \\
\hline Non-metallic mineral products industry & 0.0409 & -0.1571 & -0.0746 & -0.0391 & -0.0574 \\
\hline Metal products,smelting and rolling processing industry & 0.1038 & -0.1949 & -0.2969 & 0.0217 & -0.0915 \\
\hline Equipment manufacturing & 0 & 0 & 2.1677 & -0.5688 & 0.3997 \\
\hline Electricity,water and gas production & 0.0328 & 0.0904 & -0.427 & -0.4464 & -0.1875 \\
\hline Construction industry & 0.0921 & 0.0026 & -0.0008 & -0.0088 & 0.0212 \\
\hline Transportation,warehousing and postal services & -0.034 & 0.5694 & -0.3673 & -0.1649 & 0.0007 \\
\hline Wholesale and retail trade & 0.0282 & 0.0092 & -0.717 & 1.716 & 0.2591 \\
\hline Accommodation and catering & 0.1255 & 0.0141 & 0.0323 & -0.3316 & -0.0398 \\
\hline Financial industry & 0.03834 & 0.0049 & 0.0119 & 0.0073 & 0.0156 \\
\hline Real estate & 0.1377 & 0.0133 & -0.0105 & -0.0801 & 0.0151 \\
\hline Profitable service industry & -0.0441 & 0.0016 & 0.0068 & -0.0525 & -0.022 \\
\hline Non-profit service industry & 0.0431 & 0.0119 & 0.0075 & -0.1304 & -0.0169 \\
\hline Total Output & 0.0361 & 0.0203 & -0.1148 & 0.0257 & -0.0081 \\
\hline
\end{tabular}

Table3. Number of Employees at Each Industrial Sector of Kashgar City Circle in 2012-2016 Unit: people

\begin{tabular}{|c|c|c|c|c|c|}
\hline Industrial Sector & 2012 & 2013 & 2014 & 2015 & 2016 \\
\hline Agriculture,forestry,animal husbandry and fisheries & 5505 & 4720 & 5323 & 5324 & 4399 \\
\hline Extractive industry & 2527 & 3532 & 1471 & 2695 & 1950 \\
\hline Food processing & 1296 & 1705 & 1963 & 2220 & 2957 \\
\hline Textile and clothing industry & 1828 & 940 & 1423 & 2939 & 9361 \\
\hline Wood processing,furniture,paper,printing industry & 410 & 486 & 839 & 1008 & 1053 \\
\hline $\begin{array}{l}\text { Medicine,rubber,chemical raw materials and chemical products } \\
\text { manufacturing }\end{array}$ & 419 & 882 & 828 & 1031 & 1238 \\
\hline Non-metallic mineral products industry & 4573 & 4090 & 4246 & 4563 & 4310 \\
\hline Metal products,smelting and rolling processing industry & 2292 & 2583 & 1806 & 1785 & 2301 \\
\hline Equipment manufacturing & 275 & 244 & 489 & 449 & 2559 \\
\hline Electricity,water and gas production & 6418 & 6892 & 6835 & 3524 & 3559 \\
\hline Construction industry & 22935 & 18442 & 16936 & 13321 & 14984 \\
\hline Transportation,warehousing and postal services & 5914 & 6152 & 6468 & 7152 & 6762 \\
\hline Wholesale and retail trade & 7345 & 7619 & 7092 & 7361 & 7416 \\
\hline Accommodation and catering & 927 & 2136 & 2047 & 2394 & 2419 \\
\hline Financial industry & 6067 & 7529 & 7464 & 7450 & 7416 \\
\hline Real estate & 1461 & 2714 & 3185 & 3564 & 3158 \\
\hline Profitable service industry & 10234 & 10533 & 12653 & 18105 & 19507 \\
\hline Non-profit service industry & 171353 & 176347 & 182543 & 185844 & 195609 \\
\hline Total population & 251779 & 257546 & 263611 & 270729 & 290958 \\
\hline
\end{tabular}

Data Sources: Statistical Yearbook of Kashgar Region and Kizilsu Kirgiz Region in 2013-2017

As can be seen from Table 3,from 2012 to 2016 , the industries with a significant increase in the employment population include food manufacturing, textiles and clothing, wood processing,furniture,papermaking,printing,medicine,rubber,che mical raw materials and chemical manufacturing, equipment manufacturing, accommodation and catering, real estate, and profitable services; among them, the employment of the equipment manufacturing industry increased by $830 \%$ in 2016 compared with 2012; the employment of the textile industry and clothing industry increased by $412 \%$ in 2012 compared with 2012; the employment of the pharmaceutical, rubber, chemical raw materials and chemical products manufacturing industry in 2016 compared with 2012 An increase of 195\%; the number of employed people in the accommodation and catering industry, as well as wood processing, furniture, paper and printing industries increased by more than $150 \%$ in 2016 compared with 2012 .

From 2012 to 2016,the industrial sectors with a larger reduction in the employment population include extractive rate of $15.56 \%$, and the growth rate is not large,as shown in Table 3. 
Table4. Labor Production Rate of Each Industrial Sector of Kashgar City Circle in 2012-2016 Unit: 10,000 yuan /person

\begin{tabular}{|c|c|c|c|c|c|}
\hline $\begin{array}{l}\text { Industrial Sector } \\
\end{array}$ & 2012 & 2013 & 2014 & 2015 & 2016 \\
\hline Agriculture,forestry,animal husbandry and fisheries & 335.80 & 429.72 & 421.11 & 452.51 & 625.26 \\
\hline Extractive industry & 77.50 & 77.21 & 186.79 & 84.12 & 107.61 \\
\hline Food processing & 121.38 & 123.04 & 124.93 & 108.90 & 105.59 \\
\hline Textile and clothing industry & 35.30 & 30.57 & 40.30 & 28.22 & 16.99 \\
\hline Wood processing,furniture,paper,printing industry & 5.68 & 6.38 & 10.49 & 36.98 & 33.92 \\
\hline $\begin{array}{l}\text { Medicine,rubber,chemical raw materials and chemical products } \\
\text { manufacturing }\end{array}$ & 112.57 & 45.12 & 60.99 & 53.42 & 72.37 \\
\hline Non-metallic mineral products industry & 48.45 & 69.03 & 63.92 & 60.45 & 69.10 \\
\hline Metal products,smelting and rolling processing industry & 32.39 & 132.39 & 172.54 & 139.20 & 125.86 \\
\hline Equipment manufacturing & 0.00 & 0.00 & 32.92 & 126.65 & 10.73 \\
\hline Electricity, water and gas production & 49.45 & 56.32 & 70.60 & 87.80 & 69.31 \\
\hline Construction industry & 30.18 & 48.37 & 60.63 & 90.65 & 90.63 \\
\hline Transportation,warehousing and postal services & 30.86 & 33.97 & 58.71 & 34.17 & 32.46 \\
\hline Wholesale and retail trade & 81.61 & 96.28 & 109.89 & 107.71 & 95.08 \\
\hline Accommodation and catering & 125.19 & 70.68 & 80.68 & 85.20 & 70.49 \\
\hline Financial industry & 21.55 & 21.30 & 26.38 & 30.54 & 37.90 \\
\hline Real estate & 78.40 & 49.69 & 42.20 & 40.65 & 39.98 \\
\hline Profitable service industry & 21.65 & 25.02 & 24.23 & 17.95 & 18.31 \\
\hline Non-profit service industry & 5.57 & 6.62 & 7.21 & 9.07 & 8.57 \\
\hline Labor production rate per person & 32.01 & 32.41 & 31.36 & 28.37 & 23.59 \\
\hline
\end{tabular}

Table5. Labor Production Rate of Each Industrial Sector of Kashgar City Circle in 2013-2016 Unit: 100\%

\begin{tabular}{|c|c|c|c|c|c|}
\hline Industrial Sector & 2013 & 2014 & 2015 & 2016 & $\begin{array}{c}\text { Average } \\
\text { growth rate }\end{array}$ \\
\hline Agriculture,forestry,animal husbandry and fisheries & 0.2797 & -0.0200 & 0.0746 & 0.3818 & 0.1790 \\
\hline Extractive industry & -0.0037 & 1.4195 & -0.5496 & 0.2791 & 0.2863 \\
\hline Food processing & 0.0136 & 0.0154 & -0.1283 & -0.0304 & -0.0324 \\
\hline Textile and clothing industry & -0.1339 & 0.3180 & -0.2997 & -0.3979 & -0.1284 \\
\hline Wood processing,furniture,paper,printing industry & 0.1224 & 0.6444 & 2.5258 & -0.0827 & 0.8025 \\
\hline $\begin{array}{l}\text { Medicine,rubber,chemical raw materials and } \\
\text { chemical products manufacturing }\end{array}$ & -0.5991 & 0.3516 & -0.1241 & 0.3546 & -0.0043 \\
\hline Non-metallic mineral products industry & 0.4245 & -0.0739 & -0.0543 & 0.1430 & 0.1098 \\
\hline $\begin{array}{l}\text { Metal products,smelting and rolling processing } \\
\text { industry }\end{array}$ & 3.0867 & 0.3033 & -0.1932 & -0.0959 & 0.7752 \\
\hline Equipment manufacturing & 0.0000 & 0.0000 & 2.8466 & -0.9153 & 0.4828 \\
\hline Electricity, water and gas production & 0.1389 & 0.2535 & 0.2436 & -0.2106 & 0.1063 \\
\hline Construction industry & 0.6029 & 0.2534 & 0.4952 & -0.0003 & 0.3378 \\
\hline Transportation,warehousing and postal services & 0.1008 & 0.7281 & -0.4180 & -0.0500 & 0.0902 \\
\hline Wholesale and retail trade & 0.1797 & 0.1414 & -0.0199 & -0.1173 & 0.0460 \\
\hline Accommodation and catering & -0.4354 & 0.1415 & 0.0561 & -0.1727 & -0.1026 \\
\hline Financial industry & -0.0116 & 0.2385 & 0.1575 & 0.2412 & 0.1564 \\
\hline Real estate & -0.3662 & -0.1508 & -0.0368 & -0.0165 & -0.1426 \\
\hline Profitable service industry & 0.1555 & -0.0316 & -0.2593 & 0.0199 & -0.0289 \\
\hline Non-profit service industry & 0.1889 & 0.0897 & 0.2577 & -0.0550 & 0.1203 \\
\hline Labor production rate per person & 0.2025 & 0.1052 & 0.0338 & -0.0125 & 0.0822 \\
\hline
\end{tabular}

As seen from table 5,from 2013 to 2016,the industrial sectors with positive average productivity growth rate are agriculture, forestry, animal husbandry and fishery, wood processing, furniture, papermaking, printing, metal products, smelting and rolling processing, equipment manufacturing, construction industry, electricity, water and gas production industry, transportation, warehousing and postal industry, wholesale and retail industry, finance industry, non-profit service industry. Although the average growth rate of labor productivity in the extractive industry is positive, the industrial development is not very good in view of its output value and the actual situation of the employed population. In addition, the average growth rate of labor productivity in other industrial sectors is negative, indicating that these industrial sectors have not reached the scale effect or the effect of technological progress is not obvious.

Based on the above analysis,the overall industrial development of Kashgar City Circle has not achieved the desired results. The total output value not only did not increase from 2012 to 2016,but also decreased.After summarizing, only $18 \%$ of the 18 industrial sectors have increased their output value year by year.At the same time,some labor productivity has also increased significantly.About $50 \%$ of the industrial sector is lacking in development. 


\section{Policy Suggestions for the Industrial Development of Kashgar City Circle in the Context of the Silk Road Economic Belt}

Kashgar City Circle currently has 14 cities and towns in 2 cities.In 2017, the total population of Kashgar City Circle was 5,270,300.At present,the proportion of industrial structure is 31.1:26.5:42.4, which belongs to the structure of "Third-One Two". The tertiary industry has developed,but the proportion of agriculture is too large, and the proportion of industry is relatively small.According to the expected industrial structure target of 20.5:34.3:45.2 of the 13th Five-Year Plan (2020), which shows that the industry of Kashgar City Circle will realize the transformation of the "three one two" to "three two one" model in 2020 .

According to the "Thirteenth Five-Year Plan for National Economic and Social Development in the Kashgar Region" and the "Thirteenth Five-Year Plan for National Economic and Social Development in the Kizilsu Kirgiz Region",this paper makes recommendations in the following areas:

\subsection{Focus on the construction of "Five Centers" and establish key development of leading industries}

According to the construction of "Five Centers", we will accelerate the construction of district transportation hub centers, trade and logistics centers, financial service centers, cultural technology centers, medical service centers, and regional financial centers.

First of all,Kashgar City Circle is located in an important node position of the new The Silk Road economic belt.It is China's window to Central Asia and even Europe.It is similar to the location of the Greater Chicago metropolitan area.It is a transportation hub in the western region,speeding up the construction of an integrated transportation system and expanding the space for infrastructure construction.It is necessary to strengthen the construction of transportation interconnection facilities with Central Asia and South Asian countries and inland cities and inland areas,build a comprehensive transportation corridor of highways,railways and civil aviation,and turn Kashgar into an important regional transportation hub of The Silk Road economic belt and an important node city of the national strategic resource transportation channel.These all require the rapid development of the construction industry.

Secondly,the proposal of the transportation hub will inevitably promote the development of the trade and logistics center. The construction of the transportation hub and the development of the trade and logistics industry will inevitably increase the demand for regional funds and cause the inflow of funds, which will further promote the development of the financial industry.Finance is the core of the modern economy,innovative financial services, better play the role of finance in supporting the industrial structure adjustment, and enhance financial support for the real economy of Kashgar City Circle.
Therefore, from the current development trend, the development of the construction industry, wholesale and retail industry, transportation, warehousing and postal industry in three industries should be the key development industry of Kashgar City Circle. But after a period of time, the financial industry should become one of the leading industries of Kashgar City Circle.

\subsection{Focus on the development of leading industries and promote the development of auxiliary industries}

The construction of the transportation hub is inseparable from the advance development of the construction industry, and the construction of the energy information channels of China, Pakistan, China and Kyrgyzstan and China Tower. The construction of the Central Asia Information Channel, China-Pakistan Optical (fiber) cable channel and domestic transmission channel in order to cooperate to improve the capacity of the Kashgar International Satellite Hub ground station; and the construction of various industrial parks, etc., not only the development of the construction industry but also the manufacture of equipment Industry, wood processing, furniture, paper and printing, and financial industries.

It is necessary to persist in taking new industrialization as the first driving force for economic and social development, and consider the relationship between employment and industrial development as a whole. On the basis of transforming traditional industries, it is necessary to accelerate the cultivation of emerging industries, create an industrial system with regional characteristics of Kashgar City Circle, and comprehensively improve the overall level of industrialization. In addition, it is necessary to optimize the spatial layout of industrial development, mainly to build the park industry, focusing on the development of new industries such as commerce, logistics, finance, electronic information, textile industry, building materials industry, machinery manufacturing, etc., and to promote the establishment of Kashgar equipment manufacturing manufacturing and export base, South Xinjiang (Kashgar, Aksu) international stone, ceramics and home decoration building materials industry gathering area, international trade and logistics center, furniture building materials export base and other international emerging industrial centers.

Kashgar City Circle construction industry, wholesale and retail industry, transportation, warehousing, postal industry take three industries as the current key industry development. The auxiliary industries of the three industries should be identified as wood processing, furniture, paper and printing industries, equipment manufacturing and financial industries.

\subsection{Upgrade traditional basic industries and accelerate industrial modernization}

Agriculture is the basic traditional industry of Kashgar City Circle for a long time.About $50 \%$ of the 16 cities and towns are agricultural pillar industries.Maigaiti County is 
dominated by agricultural industries, and the development of other industries is very backward.Therefore, as the Kashgar City Circle dominated by the agricultural industry,it is necessary to retain the development of traditional industries during the transformation process, but it is necessary to accelerate the modernization of agriculture.At the same time, it is necessary to extend the agricultural industry chain and develop related agricultural and sideline food processing industries, etc., to gradually promote the development of the agricultural industry.

The agricultural and animal husbandry areas in the national-level Tarim River desertification prevention ecological function area and the autonomous region-level desert ecological function area in the northwest of the Tarim Basin are distributed in Kashgar City,Shufu County,Shule County,Yuepu Lake County,Jiashi County,Bachu County and other regions.Abundant water resources are advantageous resources for arable land and pasture grazing. The agriculture in the towns near the Kashgar City Circle's watershed has the conditions for sustainable development.Therefore,adjusting the spatial layout of the agricultural industry,optimizing the structure of the agricultural industry,promoting the industrialization of agriculture, and building the integrated development of modern agriculture have become key issues for the agricultural industry.

\subsection{Reasonably develop resources to drive the development of related industries}

It is necessary to combine the resources of Kashgar City Circle,scientifically and rationally investigate,develop,utilize and protect mineral resources, and further improve the guarantee of mineral resources for economic and social development.At the same time, it is necessary to actively develop the extractive industry to promote the structural adjustment and upgrading of the steel industry and the development of related industries in the mineral resources of Shule County,Shache County,Jiashi County,Akto County,and Uqia County.At the same time, it is necessary to actively develop petroleum,natural gas,refining and chemical products and mid- and downstream products, and accelerate the development of integrated refining and chemical products.Moreover,we need to rely on the construction of China-Pakistan oil pipelines,develop petrochemical enterprises, and plan Gwadar Port-Kashgar crude oil transfer station in "one city,two counties" and surrounding areas.

Build a cultural tourism center.The geographical location of Kashgar City Circle is very advantageous, with many natural scenic areas,such as the ancient city of Kashgar,Dawakun Desert Scenic Area,Golden Populus National Forest Park,Chogori Peak,Chess Thousand Buddha Caves,Taklimakan Desert,Mustaq Scenic Area,Gongge Erfeng,Yuqi Tash Grassland,Red Valley Scenic Area,Toshigan Valley scenery and other natural monuments.It is necessary to accelerate the Kashgar City Circle the Silk Road culture,national customs international tourism distribution center and destination,and build a regional cultural tourism center as soon as possible.

Kashgar City Circle has more natural resources and can be rationally exploited and developed within the scope of government planning to promote the development of extractive industries and related industries.At the same time, it has many places of interest and beautiful natural scenery,which can vigorously promote the development of tourism, and the development of tourism can also promote the development of commercial logistics and accommodation and catering.

\section{Conclusion}

At present, according to the in-depth analysis of the 18 industrial sectors of Kashgar City Circle,the industrial development of Kashgar City Circle is not good, but the proposal of the new The Silk Road economic belt initiative has brought huge development opportunities to Kashgar City Circle. Therefore, combined with the analysis in this article, the construction industry, wholesale and retail industry, transportation, warehousing and postal industries of Kashgar City Circle should take the three industries as the key industry development at this stage. The auxiliary industries of the three industries should be identified as wood processing, furniture, paper and printing industries, equipment manufacturing and financial industries. At the same time, it is necessary to take into account the development of agriculture, extractive industries and tourism, in order to drive the overall development of the Kashgar City Circle economy.

\section{Acknowledgment}

This paper is the result of Soft Science Project of Xinjiang Uygur Autonomous Region Natural Fund (Project No.2018D07023), Jiangsu Post-doctoral Research Grant Program (Project No.1701102C),"Research on Industrial Transition and Development of Kashgar Urban Agglomeration Based on Silk Road Economic Belt Strategy".

\section{References}

1. Bai Xiao,Lu Wen,Zhang Rong.Measurement and Analysis of Industrial Structure Order in Kashgar City Circle Based on Order Model of Industrial Structure[C].2020 The 3rd International Conference on Computers in Management and Business,Association for Computing Machinery.2020,01:253-260

2. Bai Xiao,Pan Jie,Li Lingyan.Measurement and Analysis of Industrial Isomorphism of Kashgar Urban Agglomeration Based on Degree of Grey Incidence Model[C].2020 The 3rd International Conference on Computers in Management and Business,Association for Computing Machinery.2020,01:228-232

3. Bi Jian,Li Yuezheng,Jiang Haixu,Zhou Cheng.Research on Kashi - Atushi Combined City in the Context of Kashgar Special Economic Zone [J].World Geography Research.2014,3(1)(23):122- 
129

4. Bai Xiao,Pan Yilun,Chen Hui,Mao Wei.Study on Industry Selection of Comparative Advantages of Towns in Kashgar Urban Agglomeration under the Background of Silk Road Economic Belt [J].Global Market.2019,34:1-4

5. Bai Xiao,Kong $\mathrm{Na}$,Chen Hao.Research on Countermeasures for Industrial Transformation and Development of "Kashgar Urban Agglomeration" Based on Silk Road Economic Belt Background [J].Consumption Guide.2020,1: 110-113

6. Rui Wang.Research on Industrial Structure Adjustment of Kashgar Special Economic Zone in Xinjiang [D].Xinjiang University.2012

7. Zhang Congguo,Sheng Ming,Yang Mei.Discussion on the Path of Industrial Development in Kashgar City Based on Employment Orientation [C].Proceedings of the Urban Planning Society of China Conference.2011,9: 3069-3078

8. Dilinur Abreu.An Analysis of the Impact of "the Belt and Road Initiative" on Kashgar's Industrial Structure Optimization [J].National Business Situation.2016,29: 50-51

9. Sulaiman Slamu,Shamiya Kamili River,Oman Guli.Analysis on Optimization of Industrial Structure in Kashgar Region [J].Economic Circles.2016,2:8090

10. Wang Fengxiao.Combination Forecast and Structure Analysis of Value Added of Primary Industry in Kashgar Region [J].Statistics and Management.2018.12:22-25

11. Wu Lin,Liu Weizhong.Comparative Analysis of Rural Economic Development in Typical Areas of Xinjiang-Taking Kashgar and Changji as Examples [J].Agricultural Outlook.2019.4: 34-37+55

12. Bai Xiao,Yang Yanling,Chen Hui.Research on the Geographical Location and Industrial Development of Kashgar Urban Agglomeration Based on the Silk Road Economic Belt [J].Economic and Trade Practice.2019,8:67-68

13. Li Xuejun,Song Yaohui,Xiang Li.Fixed Assets Investment and Industrial Structure Changes under the Background of Aid to Xinjiang: An Empirical Analysis of Kashgar Region [J].Journal of Bingtuan Party School.2014.2:74-79

14. Bai Xiao.Research on Fixed Assets Investment and Industrial Development in Kashgar Region under the Background of Silk Road Economic Belt [J].Global Market.2019,5:1-2+6 